Olga Wesołowska*

\title{
ZAWODNICY Z LIGI PRZEKLĘTYCH \\ - GETTA WSPÓŁCZESNYCH NIEMIEC I ICH REPREZENTACJE W TWÓRCZOŚCI FERIDUNA ZAIMOGLU
}

Getto - to słowo budzi jednoznaczne skojarzenie, odizolowane dzielnice tworzone przez nazistów w czasie II wojny światowej, głównie dla ludności żydowskiej. Jednak getta powstają też we współczesnym świecie, m.in. w Niemczech. Często eufemistycznie - by nie budzić złych skojarzeń z niemiecką przeszłością - nazywane są dzielnicami migrantów (niem. Migrantenviertel), problematycznymi dzielnicami (niem. Problemviertel) lub społecznymi punktami zapalnymi (niem. sozialer Brennpunkt). Szczególnie w topografii dużych miast zaznaczają one swoją obecność. Na przykład w Berlinie czy Kolonii takich dzielnic jest już kilka. Powiększanie się gett często kojarzy się z kryzysem uchodźczym i polityką Angeli Merkel głoszącą hasła „Niemcy są krajem imigracji” (niem. Deutschland ist ein Einwanderungsland) oraz „Damy radę” (niem. Wir schaffen das). Problem tworzenia się gett we współczesnych Niemczech trzeba rozpatrywać w szerszej perspektywie, ponieważ proces gettoizacji rozpoczął się już dużo wcześniej.

W Niemczech migracja ma długą historię. Najwięcej imigrantów przybyło do tego kraju po zakończeniu II wojny światowej. Było to związane ze zmianami granic i przesiedleniami osób niemieckiego pochodzenia. Już wcześniej w Niemczech osiedlało się dużo obcokrajowców. Wystarczy wspomnieć tysiące robotników z Polski, którzy w drugiej połowie XIX wieku wyjechali do pracy w Zagłębiu Ruhry (Berlinghoff 2018). Ta ogromna grupa ${ }^{1}$ dość szybko się zintegrowała. O Polakach mówi się nawet „niewidzialni migranci” (Loew 2017), chociaż tworzą drugą co do wielkości mniejszość narodową w tym kraju. Największą stanowią Turcy i to oni w dużym stopniu podlegają procesowi gettoizacji, ale nie tylko.

* Mgr Olga Wesołowska, Uniwersytet Łódzki.

1 Ta grupa powiększała się w kolejnych latach m.in. o przymusowych robotników z czasów II wojny światowej (niektórzy nie wracali do Polski) oraz osoby emigrujące w czasach PRL-u do Niemiec. 
Problem tworzenia się gett w Niemczech jest dużo bardziej złożony, ponieważ nie dotyczy on wyłącznie jednej narodowości albo wyznawców jednej religii. Nawet jeśli wiele osób kojarzy dzielnice migrantów z muzułmanami, to w gettach żyją też osoby innych wyznań. Przykładem mogą być skupiska Rosjan. Tak jest w małej miejscowości Waldbröl koło Kolonii, nazywanej rosyjskim gettem, ponieważ 20\% mieszkańców to tzw. Russlanddeutsche (Steiner 2018).

Powstawanie gett jest wynikiem wielu politycznych decyzji, które zapadły po zakończeniu II wojny światowej. Najważniejsza z nich pochodzi z roku 1955. Wtedy Republika Federalna Niemiec podpisała umowy dwustronne dotyczące przyjazdu do kraju robotników z zagranicy. Tzw. gastarbeiterzy (od niem. Gastarbeiter - pracownik gościnny) pochodzili głównie z Włoch, Turcji, Portugalii, Hiszpanii, Grecji oraz krajów byłej Jugosławii. Na początku lat 70., wraz z kryzysem naftowym, Niemcy przestały przyjmować nowych gastarbeiterów, a wielu pracowników wróciło do swoich ojczyzn. Ci, którzy zdecydowali się zostać, dostali pozwolenie na łączenie rodzin. Również Niemiecka Republika Demokratyczna sprowadzała w tym czasie obcokrajowców do pracy - przede wszystkim z „zaprzyjaźnionych” krajów socjalistycznych tj. z Wietnamu, Polski (Gomerska 2015: 199-218). Znaczący - w kontekście współczesnych gett - wydaje się jednak stosunek do imigrantów w zachodnich Niemczech, który wyraża się już w samej nazwie gastarbeiter. Mieli oni tu być tylko „gościnnie”. Aydan Özoğuz, pełnomocniczka rządu RFN ds. migracji, uchodźców oraz integracji w latach 2013-2018, podkreślała - „Fundamentalnym błędem było przekonanie, że gastarbeiterzy i tak stąd wyjadą" (Mazke 2015). Nie wyjechali. Turcy do dzisiaj stanowią największą mniejszość narodową w Niemczech, a dzielnice zamieszkiwane przez nich (oraz obywateli państw arabskich) najczęściej kojarzone są gettami. To one znajdują się $w$ centrum zainteresowania tej pracy.

Na przełomie lat 70. i 80 . w niemieckiej literaturze zaczęły pojawiać się utwory opisujące doświadczenia gastarbeiterów. Wtedy zadebiutowali m.in. Franco Biondi czy Rafik Schami, a Günter Wallraff opublikował reportaż Na samym dnie. Autor udawał tureckiego gastarbeitera, aby przekonać się, jak naprawdę działa polityka integracji w Niemczech. Pozwoliło mu to ukazać ksenofobię, powszechnie panującą w kraju (Wallraff 1998). Od tego czasu dużo się zmieniło w podejściu Niemców do migrantów. Inaczej wygląda też Ehrenfeld, dzielnica Kolonii, w której Wallraff wychowywał się i mieszka do dzisiaj (Wünsch 2010). To wciąż skupisko migrantów. Przy głównej ulicy Venloer Straße nadal przeważają arabskie restauracje, sklepy. Również przy niej - od roku 2018 - funkcjonuje największy w Niemczech (i jeden z największych w Europie) meczet. Jego budowa wzbudzała wiele kontrowersji (Fritz 2018). W Ehrenfeld 1/3 mieszkańców ma tzw. Migrationshintergrund (Wünsch 2010), czyli pochodzenie imigranckie ${ }^{2}$. Jednak

2 Oznacza to, że te osoby bądź przynajmniej jedno z ich rodziców nie urodzili się w Niemczech. 
Ehrenfeld trudno określić mianem getta, ponieważ artyści odkryli je dla siebie i dzisiaj uchodzi za modną dzielnicę. Nie oznacza to, że getta zniknęły z topografii Kolonii. Po prostu przeniosły się $\mathrm{w}$ inne miejsca, dalej od popularnych kawiarni, butików i klubów - do Kalk i Müllheim³ .

Na początku mówiono o literaturze gastarbeiterów (niem. Gastarbeiterliteratur) (Buchheit 2013:4), później termin ten zmieniono na bardziej ogólny - literatura migrantów ${ }^{4}$ (niem. Migrantenliteratur) (Mauerer 2013: 10-11). Jednym z jej przedstawicieli jest Feridun Zaimoglu, który zadebiutował w latach 90. powieścią Kanak Sprak - 24 Mißtöne vom Rande der Gesellschaft (pol. Kanak Sprak - 24 źle brzmiące dźwięki z marginesu spoteczeństwa). Zdobyla ona uznanie krytyków, ale wywołała też oburzenie. Autora szybko zaczęto nazywać enfant terrible niemieckiej literatury, niemiecko-tureckim buntownikiem z getta, a także autorem kultowym (Böhmer/Zaimoglu 2004). Zaimoglu przeprowadził wywiady z wieloma mężczyznami tureckiego pochodzenia mieszkającymi w Niemczech. Kanak Sprak - 24 Mißtöne vom Rande der Gesellschaft to rodzaj poetyckiego przekładu tych rozmów. Napisany przez Zaimoglu kilka lat później Koppstoff uznawany jest natomiast za kobiecy głos z getta (Abel/Zaimouglu 2005: 159). Jednak zanim powstała jego debiutancka powieść, pisarz przez półtora roku rozmawiał z mężczyznami mieszkającymi w dzielnicach migranckich. Autor chciał znaleźć odpowiedź na pytanie, jak żyje się w Niemczech osobom z getta. Dlaczego rozmawiał najpierw tylko z mężczyznami? Zaimoglu twierdzi, że właśnie oni są twarzami getta. To ich widać, gdy wkracza się w przestrzeń zgettoizowaną. To oni biorą udział w życiu społecznym danej dzielnicy. Kobiety pozostają w domu - niewidoczne dla osób z zewnątrz (Zaimoglu 1995: 9-15).

Powieść Zaimoglu można uznać za niezwykle autentyczny głos getta już ze względu na samą warstwę językową. Pisarz posługuje się tytułowym Kanak Sprak, czyli językiem specyficznym dla głównie młodych ludzi pochodzenia tureckiego, mieszkających właśnie we współczesnych niemieckich gettach ${ }^{5}$. Nie można jednak powiedzieć, że Kanak Sprak jest odmianą młodzieżowego slangu. Osoby, które zaczęły go używać w młodości, często nadal się nim posługują. Ten specyficzny język wciąż ewoluuje. Jest to rodzaj socjolektu, który bazuje na słownictwie zaczerpniętym z języka niemieckiego oraz tureckiego. Niemiecka gramatyka oraz fonetyka poddane zostały sporym zmianom (Keim/Androutsopoulos 2000: 3-4). Autor wyjaśnia we wstępie, dlaczego używa właśnie Kanak Sprak: „Tym poetyckim przekładem chciałem stworzyć zamknięty, widoczny,

3 Ze względu na bardzo dużą społeczność turecką mieszkającą w Müllheim dzielnica nazywana jest żartobliwie przez kolończyków „Istambułem”.

4 Stosowane jest również pojęcie literatura migracji (niem. Migrationsliteratur), które zwraca uwagę na tematykę tekstów, a nie na pochodzenie autora/ki.

5 To właśnie ten specyficzny język sprawia, że książka Zaimoglu jest trudna do przetłumaczenia i nie ukazała się jeszcze na polskim rynku. 
a zarazem autentyczny obraz języka. W przeciwieństwie do literatury imigrantów tutaj Kanakowie naprawdę dochodzą do głosu w swoim własnym języku" (Zaimoglu 1995: 18) $)^{6}$ Kanak był przez wiele lat wyrazem wulgarnym, obraźliwym określeniem stosowanym wobec migrantów. Dzisiaj - jak podkreśla Zaimoglu we wstępie do trzeciego wydania Kanak Sprak - oni sami używają je w stosunku do siebie (Zaimoglu 1995: 9). Kanak z obelgi stał się synonimem osoby silnej, groźnej, a także outsidera (Keim/Androutsopoulos 2000: 2). Ich język brzmi dla Niem ców często zupełnie obco: „(...) dzieci-Kanaki poruszają się po ulicach, mówią w ciągle rozwijającym się symbolicznym żargonie, który często mylony jest z jakimś kwiecistym, orientalnym językiem" (Zaimoglu 1995: 14). Trzeba podkreślić, że używanie form niepoprawnych językowo nie wynika z niewiedzy. Nie można traktować Kanak Sprak jako braku dostatecznych kompetencji językowych. Często osoby używające tego socjolektu potrafią również mówić płynnie w języku swoich rodziców oraz po niemiecku. Wypracowany przez nich nowy język jest - według Inkena Keima oraz Jannisa Androutsopoulosa - symbolem tego, że te osoby nie czują się związane ani z tureckim, ani z niemieckim społeczeństwem. Kanak Sprak jest więc wyrazem ich własnej społeczno-kulturowej tożsamości. Potwierdzają to także słowa 13-latka, jednego z rozmówców Zaimoglu: „(..) ale mnie nie ma już tam, skąd pochodzę, nie jestem też tu, gdzie się obijam" (Zaimoglu 1995: 95) ${ }^{7}$. Natomiast o dzielnicy, w której mieszka, opowiada używając zaimka „moja”. To miejsce, w którym spędził całe życie, jest dla niego ważne jak „(...) parująca miska, którą matka stawia przede mną i mówi: jedz, żebyś był silny” (Zaimoglu 1995: 92). Pokazuje to, że tożsamość bohaterów Kanak Sprak ukształtowała przede wszystkim przynależność do społeczności migrantów $\mathrm{z}$ danej części miasta. Często określanej jako getto - zarówno przez osoby w niej żyjącej, jak i te z zewnątrz (Keim/Androutsopoulos 2000: 2-3).

Takie dzielnice znajdują się w wielu niemieckich miastach. Jedną z bardziej znanych jest berliński Neukölln. Również poza metropoliami tworzą się getta - przez policję i polityków nazywane strefami „no-go” - przykładem jest dzielnica Marxloh w Duisburgu (Gruen/Matzke: 2017). Stosunek do miejsca zamieszkania wpływa na język jego mieszkańców. Keim i Androutsopoulos twierdzą, że młodzież żyjąca w gettach dzieli się na dwie grupy - tę, która chce się z nich wyrwać oraz tę, która podkreśla swoją przynależność. Celem tej pierwszej jest dopasowanie się pod względem językowym i społecznym do standardów niemieckiego społeczeństwa (osiągnięcie tego celu zazwyczaj wiążą z wykształceniem). Natomiast druga grupa to właśnie użytkownicy Kanak Sprak (Keim/ Androutsopoulos 2000: 2).

${ }^{6}$ Wszystkie cytaty z języka niemieckiego podaję w tłumaczeniu własnym. Chyba, że zaznaczone jest inaczej.

7 Tłumaczenie cytatów z Kanak Sprak ma jedynie charakter orientacyjny. Oddany został tylko sens wypowiedzi, bez zachowania odpowiedniego kolorytu tego socjolektu. 
Zaimoglu podkreśla, że chciał pokazać tę społeczność bez upiększeń (Zaimoglu 1995: 17). Sam autor tak pisze we wstępie o rzeczywistości, którą sportretowak:

Niejeden Turek nauczył się naśladować niemieckie drobnomieszczaństwo i zamienił się w miłego kolegę »Alego «, którego po skończeniu pracy zabiera się do ulubionego lokalu. Innym udało się osiągnąć poziom uniwersytetu i bywają w niemieckich lub międzynarodowych kręgach akademickich. Dla prawdziwych intelektualistów interkulturowość była zawsze czymś oczywistym. W ten sposób zintegrowani niewątpliwie przyczynili się do czegoś w niemieckim społeczeństwie. Są oni »społecznie znośni «, nie mają żadnej społecznej sily wybuchowej. W tej książce na próżno szukać takich osób. Tutaj tylko Kanak ma głos. (Zaimoglu 1995: 18)

Wśród bohaterów Kanak Sprak znajdują się osoby, którym zazwyczaj odbiera się prawo do głosu. Są to np. narkomani, sutenerzy, pacjenci zakładów psychiatrycznych, żigolacy oraz bezrobotni. Zaimoglu rozmawia też z mężczyznami, którzy bardziej dopasowali się do społecznych norm - z uczniem, poetą, mechanikiem samochodowym czy pracownikiem śmieciarki. Wydaje się, że to bardzo zróżnicowana grupa, którą łączy jedynie tureckie pochodzenie i płeć. Jednak we wszystkich wypowiedziach obecna jest ta sama wściekłość i brak perspektywy. Pojawia się ona m.in. w wypowiedzi Hasana, wspomnianego już wcześniej 13-latka: „Chcesz wiedzieć, jaki jest mój trik, a ja chcę ci go zdradzić, tak między nami: gniew (...)" (Zaimoglu 1995: 91). Jednak najdobitniej wyraża to 22-letni Hakan, mechanik samochodowy: „Ja to wiem, gram w lidze przeklętych, tak przeklętych i zaszufladkowanych jak tylko ten prostacki Niemiec potrafi (...) niemiecki robol jest pogromową świnią, zadeptać na śmierć to dla nich sport narodowy najwyższej rangi. Więc kto tu chce mi wmówić, że ty tu jesteś tylko gościem-na-chwilę (...)” (Zaimoglu 1995: 84-86). W wypowiedziach bohaterów Kanak Sprak agresja wiąże się również z silnym podziałem na my oraz oni (Niemcy). Znajduje to wyraz w wyżej cytowanych słowach Hakana. Niechęć do Niemców przejawia wielu rozmówców Zaimoglu. Przykładowo, bezrobotny Hüdaver zaczyna swoją wypowiedź od mocnego zdania: „Niemiecki kraj to słona burdelmama (...)” (Zaimoglu 1995: 97). Ta kumulująca się agresja i bezradność są - według Zaimoglu - wspólne dla wszystkich bohaterów:

Łączy ich uczucie grania w lidzie przegranych przeciw kulturowo hegemonistycznym wymaganiom. Ważnym elementem tej społeczności jest poza tym negatywna samoświadomość, która znajduje powierzchowny wyraz w pozornym samooskarżaniu siebie jako Kanaków! To uwłaczające słowo związane z nagonką staje się słowem kluczem w poszukiwaniu tożsamości, klamrą lączącą (...). (Zaimoglu 1995: 17)

Kanak to nie jedyne słowo, które bohaterowie Zaimoglu używają w sposób subwersywny. Jeden z nich thumaczy: „(...) jesteśmy tu wszyscy razem niggerami, mamy nasze getto $(\ldots)$, ale do bycia niggerem należy całe mnóstwo bycia 
innym oraz inne życie” (Zaimoglu 1995: 25). Zawłaszczanie słów, które wiążą się z dyskryminacją (takich właśnie jak: Kanak, Nigger czy getto), służy im do podkreślenia własnej tożsamości i inności.

Norbert Gestring stawia tezę dotyczącą tworzenia się w niemieckich gettach tzw. społeczeństwa równoległego. Kulturowy wymiar tego fenomenu wiąże się właśnie z używanym językiem, ale też przestrzeganiem własnych norm ustalonych według akceptowanych w getcie wartości (Gestring 2011: 168-190). Dlatego równie trudno wydostać się z getta, jak i dostać się do niego. Nie w znaczeniu przestrzennym - to nie stanowi problemu. Wszyscy mogą tam wejść. Nie oznacza to jednak, że każdy może zrozumieć struktury społeczne, które funkcjonują w getcie. Wspomina o tym również Zaimoglu we wstępie do Kanak Sprak - „Nie było łatwo walczyć z początkową nieufnością, którą Kanakowie odczuwają wobec osób po studiach. Środki wzbudzające zaufanie były koniecznie potrzebne, żeby ich przekonać, że »nie sprzedam ich Niemcom«" (Zaimoglu 1995: 15). Strach i niechęć są więc dostrzegalne po obu stronach. Emocje te nie są motywowane względami etnicznymi. Zaimoglu jest $\mathrm{z}$ pochodzenia Turkiem, ale ze względu na swoją pozycję społeczną i finansową oraz wykształcenie jest postrzegany jako osoba spoza getta, obca, niemal wróg. Podkreśla to też jeden z jego rozmówców - „... to się da zrobić, bo to jest moja cholerna dzielnica. Ty nie mógłbyś do nich podejść, bo przyparliby cię pięknie do ściany (...)” (Zaimoglu 1995: 92).

Pisząc o tych dzielnicach, trzeba uwzględnić dwa spojrzenia - to pochodzące z getta, ale też to spoza. Bohaterka Koppstoff - drugiej książki Zaimoglu - mówi o tym, jak Niemcy - według niej - widzą getto i jego mieszkańców:

Dla nich, my Kanaki jesteśmy rozrywką, coś jak życie bohemy albo ciężkie życie na ulicy (...) w pewnym sensie to jest strach, który sami chcieli, oni chcą czegoś z ulicy i gettowych strzelców, aby wystrzelać nudę z ich ulic. Pierwszy strzał jest bardzo głośny... A potem chór owieczek: my to wiedzieliśmy od zawsze, a teraz ten Turek staje się bezczelny w naszym kraju (Zaimoglu 2011: 137).

Traktowanie życia w getcie jako rozrywkowego i barwnego ma realne przełożenie na sytuację wielu dzielnic. W niektórych niemieckich miastach dzielnice migrantów, które cieszyły się naprawdę złą sławą, zostały zaadaptowane przez artystów i stały się miejscami modnymi, hipsterskimi - pełnymi kawiarni, butików, galerii. Dowodem tego jest już wspomniany Ehrenfeld w Kolonii, ale również berliński Kreuzberg. Podobne procesy w niemieckiej stolicy można też powoli obserwować w Neukölln. Próby przemiany terenu zgettoizowanego w modną lokalizację podejmowane są we Frankfurcie nad Menem, gdzie Bahnhofsviertel od lat uznawany jest za jedną z najniebezpieczniejszych dzielnic w całym kraju (Fittkau 2019). Na pierwszy rzut oka takie działania wydają się słuszne. Jednak zmienianie oblicza tych miejsc to tylko jedna strona medalu. Druga to postępujący proces gentryfikacji w niemieckich miastach, którego przykładem jest sytuacja we wspomnianym już Neukölln. Jest to zarówno jedna z najbiedniejszych 
dzielnic w Berlinie, jak i miejsce, gdzie ceny czynszu rosną najszybciej - w przeciągu ostatnich czterech lat zanotowano już wzrost o około 60 procent. Niektórzy przeprowadzili się tam z Kreuzbergu - innej dzielnicy migrantów, która w międzyczasie stała się dla nich za droga. Wkrótce może zdarzyć się to także w Neukölln (Waldman 2017).

Wypowiedź bohaterki z powieści Zaimoglu jest ciekawa też z innego względu. Zwraca na to uwagę Maria Stehle w książce Ghetto Voices in Contemporary German Culture: Textscapes, Filmscapes, Soundscapes. W słowach tej postaci wyraża się binarny stosunek Niemców do mniejszości tureckiej. Z jednej strony postrzegają ich życie jako przejaw czegoś egzotycznego, fascynującego, budzącego zainteresowanie. $\mathrm{Z}$ drugiej strony zaznacza się też silna opozycja my-oni ${ }^{8}$, która ujawnia się w momencie problemów, konfliktów (Stehle 2012: 1). Warto pamiętać, że egzotyzacja jest silnie związana $\mathrm{z}$ rasizmem i procesami stygmatyzacji. Ta wypowiedź budzi skojarzenia z tym, co Edward W. Said opisywał w słynnym dziele Orientalizm (Said 1991). Orient według Saida jest łączony - z eurocentrycznej perspektywy - właśnie z egzotyką, zmysłowością, ale równocześnie z zacofaniem i niebezpieczeństwem. Autor zaznacza, że nie jest to interpretacja ani analiza Orientu, lecz jedynie pewnego rodzaju europejski konstrukt i dyskurs o orientalnych krajach. Również w przypadku tureckiej mniejszości w Niemczech można mówić o projektowaniu pewnego obrazu. Nie jest on ani reprezentatywny, ani nie jest żadną interpretacją. Jest jedynie konstruktem, który służy zachodniemu społeczeństwu. Dzielnice migrantów to zarówno fascynujące miejsca przyciągające artystów, jak i niebezpieczne getta.

Zaimoglu ukazuje w swojej twórczości przede wszystkie to drugie wyobrażenie o tureckiej społeczności w Niemczech - pełne uprzedzeń, lęku i podziału na my-oni. To ono tłumaczy przekonanie o tym, że dzielnice migrantów w wielu miastach uznawane są za problematyczne oraz strefy no-go. Bohaterowie Kanak Sprak to nie idealnie zintegrowani, pokazowi obcokrajowcy (Grjasnowa 2012: 57). Tak ironizuje o sobie bohaterka powieści Olgi Grjasnowy (również przedstawicielki niemieckiej literatury migracji) Rosjanin to ten, kto kocha brzozy. Wręcz przeciwnie, rozmówcy Zaimoglu pozostają niezintegrowani, żyją na marginesie społeczeństwa, o czym przypomina podtytuł książki - 24 źle brzmiące dźwięki $z$ marginesu społeczeństwa.

${ }^{8}$ Pojawia się ona także w narracji migrantów, o czym pisałam wcześniej. 


\section{Bibliografia}

Abel, Julia; Zaimoglu, Feridun (2005), »Migrationsliteratur ist ein toter Kadaver «. Ein Gespräch. W: Arnold, Heinz Ludwig (red.), Text+Kritik. Literatur und Migration, München, s. 159-165.

Berlinghoff, Marcel (2018), Geschichte der Migration in Deutschland, www.bpb.de/gesell schaft/migration/dossier-migration/252241/deutsche-migrationsgeschichte [Dostęp: 24.06.2020].

Böhmer, Daniel-Dylan; Feridun, Zaimoglu: Interview mit Feridun Zaimoglu. »Der Türkei-Beitritt wäre ein Schlag für die Islamisten «, https://www.spiegel.de/kultur/literatur /interview-mit-feridun-zaimoglu-der-tuerkei-beitritt-waere-ein-schlag-fuer-die-isl amisten-a-291978.html [Dostęp: 23.06.2020].

Buchheit, Carolin Marie (2013), Gastarbeiterliteratur. W: Höfer, Kristina (red.), Poetiken der Migration. Ein Glossar. Saarland, s. 4.

Fittkau, Ludger (2019), Bahnhofsviertel in Frankfurt am Main »Wir sind so ein bisschen das Frankfurter Soho«, https://www.deutschlandfunkkultur.de/bahnhofsviertel-i n-frankfurt-am-main-wir-sind-so-ein.1001.de.html?dram:article_id=461486 [Dostęp: 23.06.2020].

Fritz, Gabriele (2018), Die Kölner Ditib-Moschee - Eine Geschichte voller Kontroversen, https://www.welt.de/regionales/nrw/article181672736/Koelner-Ditib-Mosche e-Eine-Geschichte-voller-Kontroversen.html [Dostęp: 23.06.2020].

Gestring, Norbert (2011), Parallelgesellschaft, Ghettoisierung und Segregation - Muslime in deutschen Städten. W: Meyer, Hendrik; Schubert, Klaus (red.), Politik und Islam. Wiesbaden, s. 168-190.

Gomerska, Karolina (2015), Od gastarbeiterów do niemieckich obywateli - problem integracji imigrantów na terenie Republiki Federalnej Niemiec. W: „Pisma Humanistyczne", Nr XIII, Katowice, s. 199-218.

Grjasnowa, Olga (2012), Der Russe ist einer, der Birken liebt. München.

Gruen, Carsten; Matzke, Małgorzata (2017), »Strefy no-go «w Zagłębiu Ruhry. Wyzwanie dla polityki i policji, https://www.dw.com/pl/strefy-no-go-w-zag\%C5\%82\%C4 \%99biu-ruhry-wyzwanie-dla-polityki-i-policji/a-39070799 [Dostęp: 23.06.2020].

Keim, Inken; Androutsopoulos, Jannis (2000), »hey lan, isch geb dir konkret handy Deutsch-türkische Mischsprache und Deutsch mit ausländischem Akzent: Wie Sprechweisen der Straße durch mediale Verarbeitung populär werden, https://jannisandrou tsopoulos.files.wordpress.com/2010/01/migration_androutsopouloskeim_2000. pdf [Dostęp: 23.06.2020].

Loew, Peter Oliver (2017), My niewidzialni. Historia Polaków w Niemczech, (tłum. Justyna Górny). Warszawa.

Matzke, Małgorzata (2015), Gastarbeiterzy sq w Niemczech od 60 lat. „Przyczynili się do niemieckiego cudu gospodarczego", www.dw.com/pl/gastarbeiterzy-s\%C4\%85-w -niemczech-od-60-lat-przyczynili-si\%C4\%99-do-niemieckiego-cudu-gospodarcze go/a-18900328 [Dostęp: 23.06.2020].

Mauer, Sarah (2013), Migrantenliteratur. W: Höfer, Kristina (red.), Poetiken der Migration. Ein Glossar. Saarland, s. 10-11.

Said, Edward W. (1991), Orientalizm, (tłum. Witold Kalinowski). Warszawa.

Stehle, Maria (2012), Ghetto Voices in Contemporary German Culture: Textscapes, Filmscapes, Soundscapes, Rochester; New York. 
Steiner, Falk (2018), Fremde Heimat. Russlanddeutsche in Waldbröl bei Köln, www.deutsc hlandfunkkultur.de/russlanddeutsche-in-waldbroel-bei-koeln-fremde-heimat.100 1.de.html?dram:article id=432975 [Dostęp: 23.06.2020].

Waldman, Ofer (2017), Gentrifizierung in Berlin-Neukölln. Der Feind meines Feindes ist mein... Nachbar, https://www.deutschlandfunkkultur.de/gentrifizierung-in-ber lin-neukoelln-der-feind-meines.976.de.html?dram:article_id=378271 [Dostęp: 23.06.2020].

Wallraff, Günter (1998), Na samym dnie, (tłum. Ryszard Turczyn). Poznań.

Wünsch, Silke (2015), Günter Wallraff: 25 Jahre $\gg$ Ganz unten $\ll$, www.dw.com/de/g\%C3 \%BCnter-wallraff-25-jahre-ganz-unten/a-6138198-0 [Dostęp: 23.06.2020].

Zaimoglu, Feridun (1995), Kanak Sprak. 24 Mißtöne vom Rande der Gesellschaft (Wydanie III). Hamburg.

Zaimoglu, Feridun (2011), Kanak Sprak/Koppstoff: Die gesammelten Mißtöne vom Rande der Gesellschaft. Köln.

Olga Wesołowska

Player in the league of the damned - ghettos in modern Germany and their representations in works of Feridun Zaimoglu

\begin{abstract}
Migration in modern world affects ghettoization. Also Germany is struggling with this problem, especially in urban areas. Immigrant neighborhoods are becoming districts which are often described as ghettos. And only do they have their own rules, but also own language - a kind of sociolect. The aim of this article is to analyze the representations of contemporary German ghettos in works of Feridun Zaimoglu (based on his novels Kanak Spark and Koppstoff).
\end{abstract}

Keywords: gehttoizaiton, Feridun Zaimoglu, Kanak Sprak, migration

Słowa kluczowe: gettoizacja, Feridun Zaimoglu, Kanak Sprak, migracja 